\title{
Treatment with Calcium Chloride Enhances Water Deficit Stress Tolerance in Viola (Viola cornuta)
}

\author{
Suejin Park, Youyoun Moon, and Nicole L. Waterland \\ Division of Plant and Soil Sciences, West Virginia University, Morgantown, \\ WV 26506
}

Additional index words. osmotic stress, osmotic treatment, postproduction, relative water content, shelf life extension, stomatal conductance, wilt status

\begin{abstract}
Water deficit stress can reduce the postproduction shelf life and marketability of floriculture crops. To alleviate the damage by water deficiency, plants need to limit transpirational water loss by inducing stomatal closure. Osmotic stress induces stomatal closure like the response to water deficit stress. It could be used as a convenient tool to enhance water deficit stress tolerance by reducing water loss. The objective of this research was to investigate whether osmotic treatment with a high concentration of chemical solutions could trigger a response to osmotic stress so that stomatal closure can be induced, resulting in enhanced water deficit stress tolerance in viola (Viola cornuta 'Sorbet XP Yellow'). Osmotic treatments with $\mathrm{CaCl}_{2}, \mathrm{Ca}\left(\mathrm{NO}_{3}\right)_{2}, \mathrm{NaCl}, \mathrm{NaNO}_{3}, \mathrm{BaCl}_{2}$, $\mathrm{Ba}\left(\mathrm{NO}_{3}\right)_{2}$, and mannitol were applied at the osmotic potentials $\left(\psi_{\mathrm{S}}\right)$ of -1.3 and -2.0 MPa. Chemical treatments [except $\mathrm{Ca}\left(\mathrm{NO}_{3}\right)_{2}, \mathrm{NaCl}$, and mannitol] helped to delay wilting and gave a longer shelf life, up to 5.2 days over that of the control, 2.5 days. However, leaf necrosis was observed on the violas treated with $\mathrm{NaCl}, \mathrm{NaNO}_{3}, \mathrm{BaCl}_{2}$, $\mathrm{Ba}\left(\mathrm{NO}_{3}\right)_{2}$, and mannitol. $\mathrm{CaCl}_{2}$ was the most effective agent in delaying wilting under water deficit stress in viola without leaf necrosis. Compared with the control, violas treated with $\mathrm{CaCl}_{2}$ at 200 and $300 \mathrm{~mm}$ showed an increase in shelf life by 2.6 and 1.2 days, respectively. Stomatal conductance $\left(g_{S}\right)$ was reduced within 4 hours after treatment with $\mathrm{CaCl}_{2}$ compared with that of control violas. Leaf relative water content (RWC) of control violas was dramatically reduced 3 days after treatment and fell below $50 \%$ on day 4 , while $\mathrm{CaCl}_{2}$-treated violas maintained higher leaf $\left.\mathrm{RWC} \mathrm{(70 \%} \mathrm{to} 81 \%\right)$ during the water deficit period. These results indicated that osmotic treatment with the high concentration of $\mathrm{CaCl}_{2}$ caused stomatal closure, resulting in a reduction of water loss and an extension of shelf life under water deficit stress in viola.
\end{abstract}

Floriculture crops are often exposed to harsh environmental conditions due to high temperatures and irregular irrigation in the retail environment. Crop loss during the postproduction period is estimated to be up to $15 \%$ of the crop (Healy, 2009). These poor postproduction conditions often cause water deficit stress, leading to decreased aesthetic values and marketability (Armitage, 1993; Sharma et al., 2006).

When encountering water deficit stress, plants need to reduce transpiration to minimize water loss. Plants can regulate transpiration by

Received for publication 6 Jan. 2020. Accepted for publication 30 Mar. 2020.

Published online 4 May 2020.

Salaries and research support were provided in part by state and federal funds appropriated to the West Virginia Agricultural and Forestry Experiment Station, West Virginia University. Scientific Article No. 3375 of the West Virginia Agricultural and Forestry Experiment Station, Morgantown.

We thank Green Circle Growers, Inc. and PanAmerican Seed for their donation of plant materials. N.L.W. is the corresponding author. E-mail: nicole. waterland@mail.wvu.edu.

This is an open access article distributed under the CC BY-NC-ND license (https://creativecommons. org/licenses/by-nc-nd/4.0/). increasing leaf stomatal resistance. Under the water deficit environment, plants synthesize a phytohormone, abscisic acid, which triggers stomatal closure to prevent transpirational water loss (Beardsell and Cohen, 1975). Using this principle, artificially blocking stomata or inducing stomatal closure using antitranspirants could be an efficient method to temporarily reduce water loss and maintain water balance. Applications of antitranspirants increased water deficit stress tolerance by reducing $g_{\mathrm{S}}$ in bedding plants (Park et al., 2016; Waterland et al., 2010a, 2010b).

Stress tolerance can be enhanced by imposing a single stressor in advance of later stresses. Earlier stress can result in improved tolerance to future stresses by helping plants respond more quickly and actively (Hossain et al., 2017; Li and Liu, 2016; Savvides et al., 2016). Among various abiotic stresses, water deficit and salt stresses may be manifested as osmotic stress to plants (Bartels and Sunkar, 2005; Wang et al., 2003). Both stresses reduce the soil water potential and lead to cellular dehydration, resulting in the disruption of homeostasis in the cell (Bartels and Sunkar, 2005). As a result, water deficit and salt stresses activate common mechanisms of cellular response, such as osmotic adjustment and antioxidant activity, and trigger similar physiological changes to withstand stresses, such as stomatal closure (Bartels and Sunkar, 2005; Wang et al., 2003; Zhang et al., 2006). However, a pre-exposure to osmotic stress has not been studied for enhancing tolerance to water deficit stress.

Calcium is well-known as a secondary messenger involved in various physiological and biochemical processes in osmotic stress in plants (Ranty et al., 2016; Tuteja and Mahajan, 2007). Abiotic stresses elevate cytosolic calcium level in plant cells, and calcium mediates stress signal transduction and activates defense mechanisms (Tuteja and Mahajan, 2007). Exogenous application of calcium has shown to ameliorate the adverse effects of salt, cold, heat, and water deficit by modulating antioxidant, growth performance, photosynthetic efficiency, and osmolytes production (Shoresh et al., 2011; Tan et al., 2011; Upadhyaya et al., 2011; Xu et al., 2013). Calcium signaling also regulates stomatal closure by inducing ion efflux from guard cells and reducing the guard cell volume (Roelfsema et al., 2012). However, no attempt has been made to determine whether the application of calcium improves water deficit tolerance by promoting stomatal closure.

The hypothesis of this research was that osmotic treatment with calcium would enhance water deficit tolerance in plants by inducing stomatal closure. The objectives of this research were to 1) determine the effects of osmotic treatment for enhancing water deficit tolerance in viola, and 2) identify the relationship between stomatal closure and water loss under water deficit in $\mathrm{CaCl}_{2}$-treated violas (Viola cornuta 'Sorbet XP Yellow'). Viola was selected in this research because it is one of the top popular bedding plants in the United States.

\section{Materials and Methods}

Expt. 1: Effects of osmotic treatment on shelf life in viola. Seeds of $V$. cornuta 'Sorbet XP Yellow' were sown in a 288-plug tray on 13 Oct. 2017, and 3-week-old seedlings were transplanted into $11-\mathrm{cm}$ pots with soilless media (Sunshine Mix \#1; Sun Gro Horticulture, Agawam, MA). Violas were grown in the greenhouse (Morgantown, WV) under natural irradiance with supplemental lighting. High-pressure sodium lamps $(600 \mathrm{~W}$ HS200 deep reflector; Hortilux, Pijnacker, The Netherlands) were turned on when natural radiance was below $50 \mathrm{~W} \cdot \mathrm{m}^{-3}$. The average daily photosynthetic photon flux density $(P P F D)$ was $197 \mu \mathrm{mol} \cdot \mathrm{m}^{-2} \cdot \mathrm{s}^{-1}$ from 0600 to $2000 \mathrm{HR}$ [mean daily light integral $\left.(\mathrm{DLI})=9.9 \mathrm{~mol} \cdot \mathrm{m}^{-2} \cdot \mathrm{d}^{-1}\right]$ with a peak $P P F D$ of $1208 \mu \mathrm{mol} \cdot \mathrm{m}^{-2} \cdot \mathrm{s}^{-1}$. Mean greenhouse temperatures were $21.7 \pm 3.6 / 17.3 \pm 2.3{ }^{\circ} \mathrm{C}$ day $/$ night (mean $\pm \mathrm{SD}$ ) with mean relative humidity of $44.3 \%$. Violas were fertigated with 20N-1.3P-15.8K (Peter Professional Petunia Special; Everris NA, Marysville, $\mathrm{OH}$ ) at 200 $\mathrm{mg} \cdot \mathrm{L}^{-1}$ nitrogen $(\mathrm{N})$. This was reduced to 100 $\mathrm{mg} \cdot \mathrm{L}^{-1} \mathrm{~N}$ one week before treatment.

Thirteen-week-old violas were irrigated with deionized (DI) water to container 


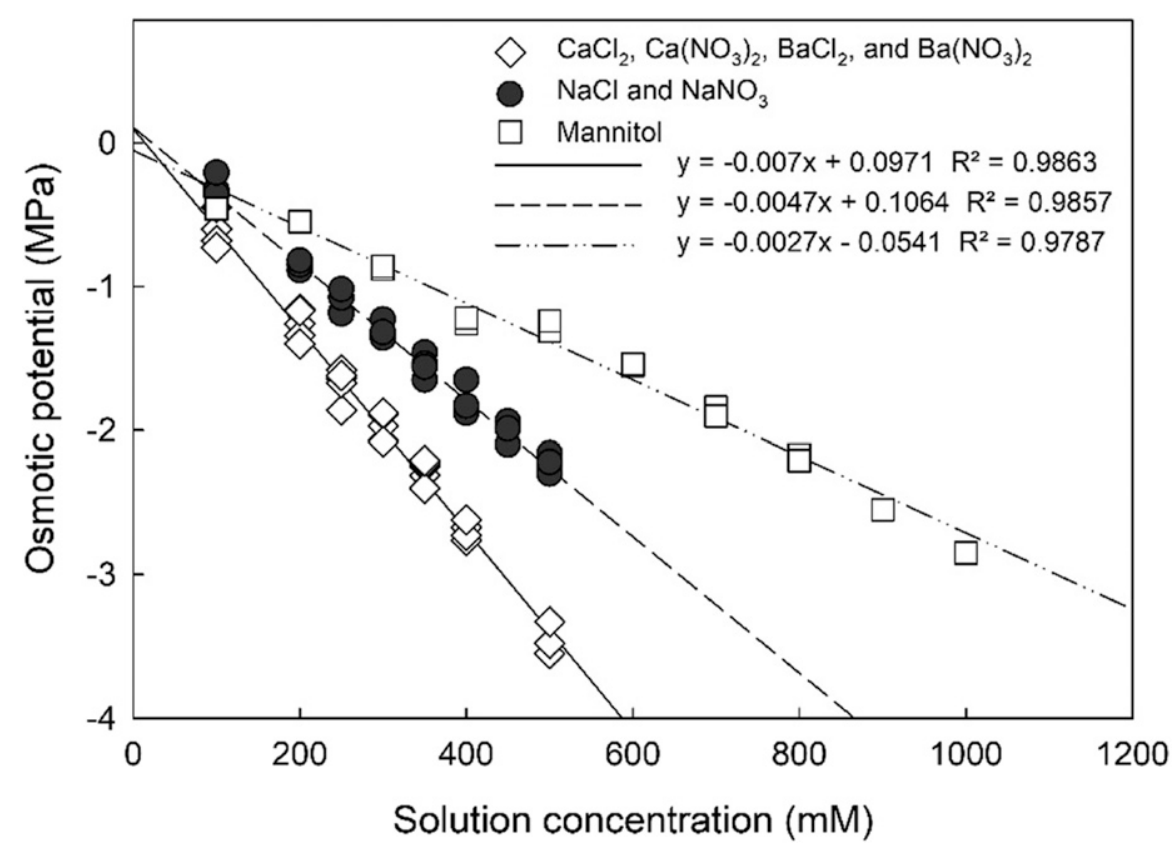

Fig. 1. Osmotic potential of chemical solutions measured with a dewpoint potentiometer. The graph shows three regression lines of divalent ion containing chemicals $(\mathrm{Ca}$ and $\mathrm{Ba})$, monovalent ion containing chemicals $(\mathrm{Na})$, and mannitol alone. The regression equations were used to calculate the chemical application concentration for each chemical. Regression analyses were performed by PROC REG (SAS Institute, Cary, NC).

capacity $12 \mathrm{~h}$ before treatment. The control treatment was drenched with DI water. Calcium treatments included $\mathrm{CaCl}_{2}$ and $\mathrm{Ca}\left(\mathrm{NO}_{3}\right)_{2}$. To distinguish whether physiological changes resulted from calcium treatment, additional sodium-containing chemicals $\left(\mathrm{NaCl}, \mathrm{NaNO}_{3}\right)$ and bariumcontaining chemicals $\left[\mathrm{BaCl}_{2}\right.$ and $\left.\mathrm{Ba}\left(\mathrm{NO}_{3}\right)_{2}\right]$ were used. As an osmotic control, mannitol was applied. Osmotic potential $\left(\psi_{\mathrm{S}}\right)$, instead of chemical concentration, was used to match the application rate of each chemical because the osmotic effect depends not only on the concentration but also on the salt ionization. The $\psi_{\mathrm{S}}$ was measured with a dewpoint potentiometer (WP4-T; Decagon Devices Inc., Pullman, WA). The osmotic application rate of calcium-containing chemicals was determined based on the preliminary experiments whose $\psi_{\mathrm{S}}$ ranged from -0.25 to $-3.39 \mathrm{MPa}$ (50 to $500 \mathrm{~mm}$ ) (S. Park, unpublished data). The values of $\psi_{\mathrm{S}}$ of low and high rates of $\mathrm{CaCl}_{2}$ and $\mathrm{Ca}\left(\mathrm{NO}_{3}\right)_{2}$ were -1.3 and $-2.0 \mathrm{MPa}$, respectively (Fig. 1). These values were used to calculate the corresponding concentrations of other chemicals. Three regression lines of divalent ion containing chemicals ( $\mathrm{Ca}$ and $\mathrm{Ba}$ ), monovalent ion containing chemicals $(\mathrm{Na})$, and mannitol alone are shown in Fig. 1. Chemicals were applied at 200 and $300 \mathrm{~mm}$ for divalent ion containing chemicals ( $\mathrm{Ca}$ and $\mathrm{Ba}$ ), 300 and $450 \mathrm{~mm}$ for monovalent ion containing chemicals $(\mathrm{Na})$, and 470 and $730 \mathrm{~mm}$ for mannitol. Violas were drenched with chemical solutions (60 $\mathrm{mL}$ per pot). Seven violas treated with each chemical had water withheld (waterstressed, $\mathrm{n}=7$ ) until all treated violas reached a visual wilt status rating of 3 or below (unmarketable) as described by Waterland et al. (2010a). Three violas of each treatment were irrigated daily with 100 $\mathrm{mg} \cdot \mathrm{L}^{-1} \mathrm{~N}$ (irrigated daily, $\mathrm{n}=3$ ) to determine whether treatments caused any side effect on the violas. Violas were irrigated $24 \mathrm{~h}$ after the application. Violas were held in the greenhouse for subsequent evaluations. The average daily $P P F D$ was 200 $\mu \mathrm{mol} \cdot \mathrm{m}^{-2} \cdot \mathrm{s}^{-1}\left(\mathrm{DLI}=10.0 \mathrm{~mol} \cdot \mathrm{m}^{-2} \cdot \mathrm{d}^{-1}\right)$, with peak $P P F D$ of $680 \mu \mathrm{mol} \cdot \mathrm{m}^{-2} \cdot \mathrm{s}^{-1}$, and the mean temperatures were $21.9 \pm 1.4 / 17.8 \pm$ $1.2{ }^{\circ} \mathrm{C}$ day/night (mean $\pm \mathrm{SD}$ ), with mean relative humidity of $43.7 \%$.

Visual observations of wilt status were taken daily. Wilt status ratings were from 1 to 5: 5 was completely turgid; 4 was soft to the touch but still upright; 3 was starting to wilt; 2 was severely wilted; and 1 was wilted to the point that the leaves are dried and desiccated (Waterland et al., 2010a). The shelf life of water-stressed violas was calculated as the number of days from the initiation of water being withheld until violas reached a wilt status rating of 3 (Waterland et al., 2010a).

Necrotic area percentage (NAP) was determined $5 \mathrm{~d}$ after osmotic treatment, using the top-view photos of daily irrigated violas. Necrotic area percentage is a proportion of necrotic area to overall plant area on the image, which is measured by pixels of the green area of leaves and the overall plant leaf area. The image color was calibrated with a color calibration chart (ColorChecker Classic, Grand Rapids, MI), and image analysis was performed with Photoshop Creative Cloud 2018 (Adobe Systems, San Jose, CA). The NAP was calculated by the following equation: $\mathrm{NAP}(\%)=100-[$ (pixels of green leaf area) / (pixels of overall plant leaf area) $\times 100$ ] (Wang et al., 2008).

Expt. 2: Wilt status, stomatal conductance, and relative water content of $\mathrm{CaCl}_{2}$-treated violas. Seeds of $\mathrm{V}$. cornuta 'Sorbet XP Yellow' were sown in a 288-plug tray on 10 Sept. 2018, and seedlings were transplanted into $11-\mathrm{cm}$ pots 3 weeks later and grown in the greenhouse as described previously. Average daily PPFD was 227 $\mu \mathrm{mol} \cdot \mathrm{m}^{-2} \cdot \mathrm{s}^{-1}$ from 0600 to $2000 \mathrm{HR}$ (DLI $=$ $11.4 \mathrm{~mol} \cdot \mathrm{m}^{-2} \cdot \mathrm{d}^{-1}$ ) with peak PPFD of 1282 $\mu \mathrm{mol} \cdot \mathrm{m}^{-2} \cdot \mathrm{s}^{-1}$. Average greenhouse temperatures were $22.0 \pm 1.0 / 17.3 \pm 1.8{ }^{\circ} \mathrm{C}$ day/night (mean $\pm \mathrm{SD}$ ), with mean daytime relative humidity of $37.5 \%$. Based on the observations from Expt. 1, $\mathrm{CaCl}_{2}$ was selected for the additional experiment. The $\mathrm{CaCl}_{2}$ solutions (200 and $300 \mathrm{~mm}$ ) were separately drenched on 13-week-old violas (60 $\mathrm{mL}$ per pot). Violas were watered to container capacity $12 \mathrm{~h}$ before application. Half of the control and $\mathrm{CaCl}_{2}$-treated violas were irrigated $(\mathrm{n}=5)$ and the other half were water-stressed $(n=5)$ by withholding water. After all water-stressed violas reached a wilt status rating of 3 or below, they were rewatered daily with DI water to container capacity to determine if there was damage such as chlorosis or necrosis by $\mathrm{CaCl}_{2}$ treatment. Violas were held in the greenhouse with daily average of $230 \mu \mathrm{mol} \cdot \mathrm{m}^{-2} \cdot \mathrm{s}^{-1} P P F D$ $\left(\mathrm{DLI}=11.6 \mathrm{~mol} \cdot \mathrm{m}^{-2} \cdot \mathrm{d}^{-1}\right)$, with peak $P P F D$ of $931 \mu \mathrm{mol} \cdot \mathrm{m}^{-2} \cdot \mathrm{s}^{-1}, 22.3 \pm 1.8 / 17.6 \pm 1.3{ }^{\circ} \mathrm{C}$ day/night temperature (mean $\pm \mathrm{SD}$ ), and $44.5 \%$ relative humidity. The visual wilt status of stressed violas was evaluated as described previously.

Stomatal conductance was measured with a portable photosynthesis system (LI-6400XT; LI-COR, Lincoln, NE). Stomatal conductance measurements were taken $1 \mathrm{~d}$ before treatment, $4 \mathrm{~h}$ after the treatment, daily, until all violas showed visual wilting, and 3 days after violas were rewatered. A leaf was inserted into an extended chamber with clear top and bottom covers (Extended Reach $1 \mathrm{~cm}$ Chamber LI6400-15; LI-COR). Environmental conditions in the chamber were set at 400 $\mu \mathrm{mol} \cdot \mathrm{mol}^{-1} \mathrm{CO}_{2}$ and $25{ }^{\circ} \mathrm{C}$ as the block temperature. Readings were recorded from 1000 to $1400 \mathrm{HR}$. Leaf RWC of an entire leaf was determined according to the following equation: RWC $(\%)=[(\mathrm{FW}-\mathrm{DW}) /(\mathrm{TW}-$ DW) $] \times 100$ (Arndt et al., 2015). Fresh weight (FW) was measured immediately after leaf collection, and dry weight (DW) was measured after drying leaves in an oven for $72 \mathrm{~h}$ at $60{ }^{\circ} \mathrm{C}$. Turgid weight (TW) was determined after fresh leaf samples were placed in a 50-ml tube with the cut end petiole submerged in DI water for $24 \mathrm{~h}$ under fluorescent light. Stomatal conductance and the leaf RWC were measured with three fully expanded leaves per plant, and the averaged value of three leaves per plant represented as one replication. Data are the means of measurements from five replications (or five plants).

Statistical analysis. Experiments were conducted as a randomized complete block design. Each plant was analyzed as one replication. Plants were blocked by replication based on 
Table 1. Shelf life, percentage of damaged plants, and necrotic area percentage (NAP) of viola (Viola cornuta) treated with chemicals.

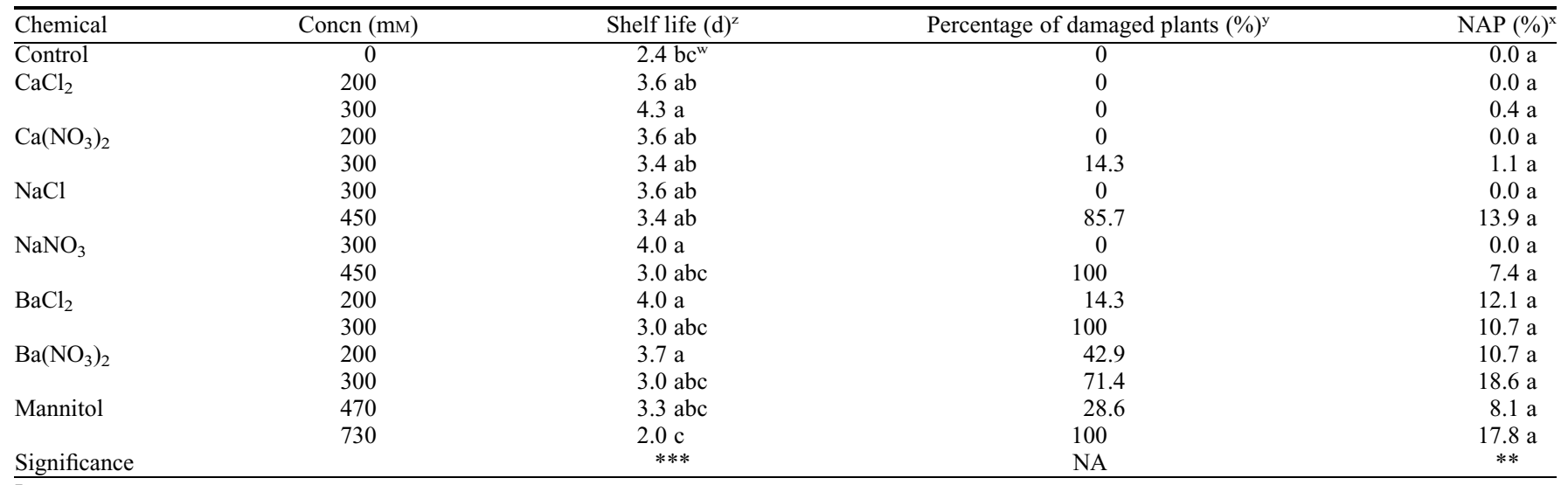

${ }^{\mathrm{z}}$ The number of days from the initiation of water being withheld until violas started showing visible symptoms of wilting. Values are means of seven replications $(\mathrm{n}=7)$.

${ }^{\mathrm{y}}$ The percentage of damaged plants out of seven treated plants under water deficit stress. Damaged violas were determined if any chlorosis or necrosis observed. ${ }^{\mathrm{x}}$ The proportion of necrotic area to overall plant area, which is measured by pixels of the green leaf area and the overall plant leaf area. The top view images of treated violas with daily irrigation for $5 \mathrm{~d}$ were used. NAP $(\%)=100-[$ (pixels of green leaf area) / (pixels of overall plant leaf area) $\times 100]$. Values are means of three replications $(\mathrm{n}=3)$.

${ }^{\text {w} M e a n ~ s e p a r a t i o n ~ b y ~ T u k e y ' s ~ s i g n i f i c a n c e ~ t e s t ~ a t ~} P \leq 0.05$.

$* *, * * *$ Significant at $P \leq 0.01$ or 0.001 , respectively.

$\mathrm{NA}=$ not applicable.

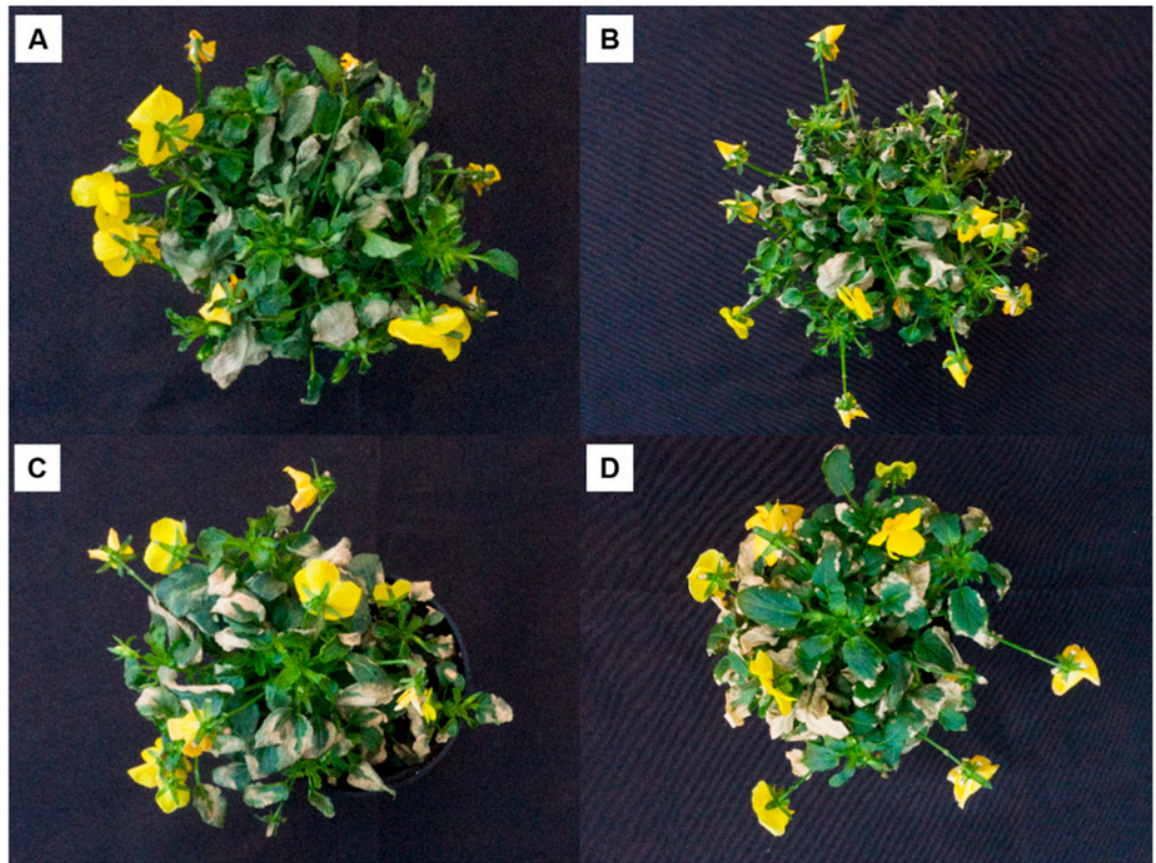

Fig. 2. Foliage damage of violas (Viola cornuta) treated by $\mathrm{NaCl}$ at $450 \mathrm{~mm}(\mathbf{A}), \mathrm{NaNO}_{3}$ at $450 \mathrm{~mm}$ (B), $\mathrm{Ba}\left(\mathrm{NO}_{3}\right)_{2}$ at $300 \mathrm{~mm}(\mathbf{C})$, and mannitol at $730 \mathrm{~mm}(\mathbf{D})$ with daily irrigation. Images were taken $5 \mathrm{~d}$ after osmotic treatments.

plant position, considering climate differences across the greenhouse, and watering regimen (irrigated daily vs. water-stressed). Analysis of variance was performed by SAS (version 9.3; SAS Institute, Cary, NC). Difference among the treatment means was assessed by Tukey's test at $P \leq 0.05$. Regression analyses were performed by PROC REG (SAS Institute).

\section{Results}

Expt. 1: Effects of osmotic treatment on shelf life in viola. Among the seven chem- icals, $300 \mathrm{~mm} \mathrm{CaCl}, 300 \mathrm{~mm} \mathrm{NaNO}_{3}$, $200 \mathrm{~mm} \mathrm{BaCl}_{2}$, and $200 \mathrm{~mm} \mathrm{Ba}\left(\mathrm{NO}_{3}\right)_{2}$ delayed wilting symptoms and extended shelf life by 1.3 to $1.9 \mathrm{~d}(P<0.0001)$, but other treatments showed no significant difference in shelf life compared with the control (Table 1). Some treatments caused leaf necrosis, especially at the higher concentration of $\mathrm{NaCl}, \mathrm{NaNO}_{3}, \mathrm{BaCl}_{2}, \mathrm{Ba}\left(\mathrm{NO}_{3}\right)_{2}$, and mannitol (Table 1, Fig. 2). Under water deficit, all treatments at the higher concentration, except the treatments with $\mathrm{Ca}$-containing chemicals, caused at least $70 \%$ of the violas to have leaf damage (Table 1) and $7.4 \%$ to $18.6 \%$
NAP on the continually irrigated violas (Table 1, Fig. 2). Overall, the Ca-containing chemicals extended shelf life the most without any significant leaf damage or necrosis. Of the two Ca-containing chemicals, $\mathrm{CaCl}_{2}$ treatment resulted in no leaf damage at all and very little necrosis (Table 1). Therefore, $\mathrm{CaCl}_{2}$ treatment was chosen for further analysis.

Expt. 2: Wilt status, stomatal conductance, and relative water content of $\mathrm{CaCl}_{2}$-treated violas. Stressed control violas started to wilt $2 \mathrm{~d}$ after treatment and reached a leaf desiccated status (wilt status rating of 1) $5 \mathrm{~d}$ after treatment, while leaves of $\mathrm{CaCl}_{2}$-treated violas remained turgid (above a wilt status rating of 3) (Fig. 3). Comparing the effects of two concentrations, violas treated with $200 \mathrm{~mm}$ $\mathrm{CaCl}_{2}$ had a higher wilt status rating than those with $300 \mathrm{~mm}$ after 3 and $4 \mathrm{~d}$ of treatment $(P<$ 0.0001) (Fig. 3). Four days after treatment, violas treated with $200 \mathrm{~mm} \mathrm{CaCl} 2$ were the most turgid under the water deficit condition, while the control violas were severely wilted (Figs. 3 and 4). Furthermore, $\mathrm{CaCl}_{2}$ treatments had a shelf life of $5.2 \mathrm{~d}$, which is twice as long as the control $(P<0.001)$ (Figs. 3 and 4 , Table 2), and $\mathrm{CaCl}_{2}$ at $200 \mathrm{~mm}$ had longer shelf life than at $300 \mathrm{~mm}$ by $1.4 \mathrm{~d}$ (Table 2 ).

To examine whether osmotic pressure caused stomatal closure, $g_{\mathrm{S}}$ was measured. Stomatal conductance rapidly decreased compared with that of control violas within $4 \mathrm{~h}$ after $\mathrm{CaCl}_{2}$ treatment in both irrigated and water-stressed violas (Fig. 5A and B). As water stress progressed, $g_{S}$ of stressed control violas became like that of $\mathrm{CaCl}_{2}$ treated violas $3 \mathrm{~d}$ after treatment (Fig. 5B). Stomatal conductance in $\mathrm{CaCl}_{2}$-treated and water-stressed violas remained low after resuming irrigation for $3 \mathrm{~d}$ (Fig. 5B). There is no difference between high and low $\mathrm{CaCl}_{2}$ concentrations in $g_{\mathrm{S}}$ under water deficit and after watering resumed (Fig. 5B). However, $g_{\mathrm{S}}$ of the stressed control was not 


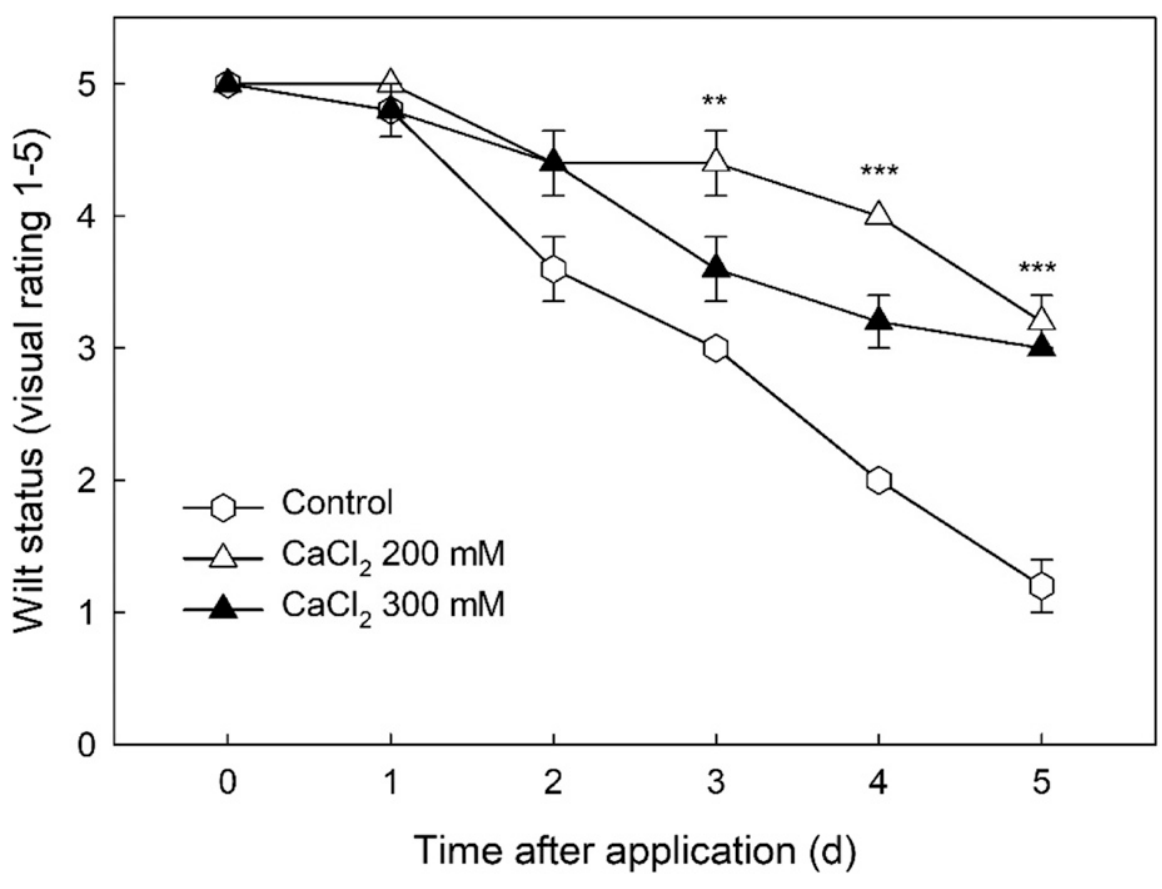

Fig. 3. Daily wilt status rating of violas (Viola cornuta) treated with $\mathrm{CaCl}_{2}$ at 200 and $300 \mathrm{~mm}$ under water deficit stress. Wilt status ratings were from 5 to 1 , where $5=$ completely turgid, $4=$ soft to touch but still upright, $3=$ starting to wilt, $2=$ severely wilted, and $1=$ wilted to the point that leaves are desiccated (Waterland et al., 2010a). Vertical bars are standard error of the means with five replications $(\mathrm{n}=5)$. **, *** Significant at $P \leq 0.01$ or 0.001 , respectively.

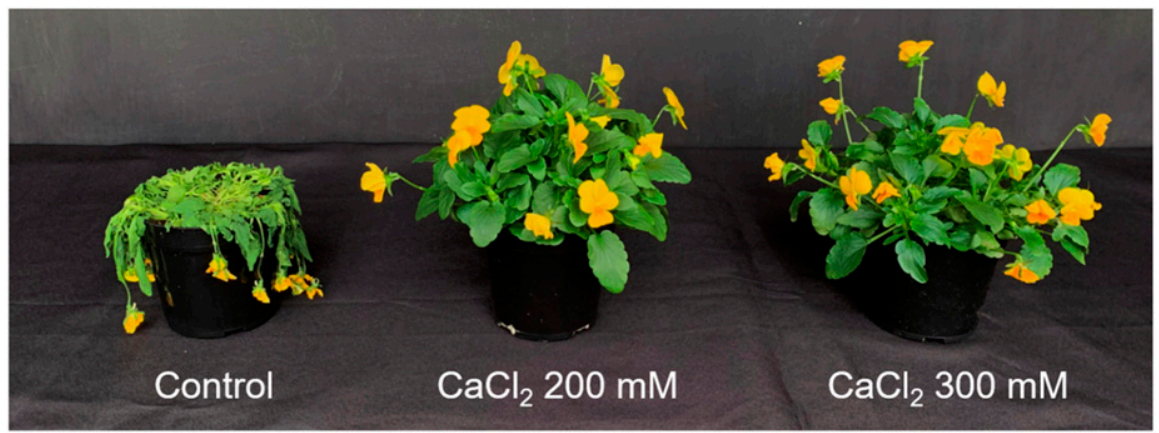

Fig. 4. Viola (Viola cornuta) control and treated with $\mathrm{CaCl}_{2}$ at 200 and $300 \mathrm{~mm}$ (from left to right). Violas were water deficit-stressed until all violas began to wilt. The image was taken $4 \mathrm{~d}$ after application of $\mathrm{CaCl}_{2}$ and water deficit

Table 2. The shelf life of $\mathrm{CaCl}_{2}$-treated viola (Viola cornuta) under water deficit.

\begin{tabular}{lcc}
\hline Chemical & Concn (mM) & Shelf life $(\mathrm{d})^{\mathrm{z}}$ \\
\hline $\mathrm{Control}$ & 0 & $2.6 \mathrm{c}^{\mathrm{y}}$ \\
$\mathrm{CaCl}_{2}$ & 200 & $5.2 \mathrm{a}$ \\
& 300 & $3.8 \mathrm{~b}$ \\
Significance & & $* * *$ \\
\hline
\end{tabular}

${ }^{\mathrm{z}}$ The number of days from the initiation of water being withheld until violas started showing visible symptoms of wilting. Values are means of five replications $(\mathrm{n}=5)$.

${ }^{y}$ Mean separation by Tukey's significance test at $P \leq 0.05$.

$* * *$ Significant at $P \leq 0.001$.

measurable because they were severely desiccated after $5 \mathrm{~d}$ of water deficit (Fig. 5B). In contrast to the water-stressed violas, when irrigated daily, the $g_{\mathrm{S}}$ of $\mathrm{CaCl}_{2}$-treated violas decreased, and then it gradually increased after treatment and regained the level of $g_{S}$ like that of irrigated controls $7 \mathrm{~d}$ after treatment (Fig. 5A). With daily irrigation, a faster increase of $g_{S}$ was ob-
92\% (Fig. 5D). However, the leaf RWC of stressed controls were dramatically reduced $3 \mathrm{~d}$ after treatment and continued to decrease to $50 \%$ after $4 \mathrm{~d}$ of treatment (Fig. 5D). In contrast, the leaves of $\mathrm{CaCl}_{2}$-treated violas maintained leaf RWC above $70 \%$ during the water deficit stress (Fig. 5D). Leaf RWC of violas treated with $200 \mathrm{~mm} \mathrm{CaCl} 2$ was generally higher than those treated with $300 \mathrm{~mm}$ $\mathrm{CaCl}_{2}$ after $4 \mathrm{~d}$ of water deficit until the end of the rewatering period (Fig. 5D). Leaf RWC of the stressed control violas was not measured after $4 \mathrm{~d}$ due to the desiccation of the violas (Fig. 5D).

\section{Discussion}

Water deficit stress is one of the major threats to postproduction decline in the floriculture industry. Chemicals were applied at two rates whose $\psi_{\mathrm{S}}$ was -1.3 and $-2.0 \mathrm{MPa}$, respectively (Fig. 1). The applications of $\mathrm{CaCl}_{2}, \mathrm{NaNO}_{3}, \mathrm{BaCl}_{2}$, and $\mathrm{Ba}\left(\mathrm{NO}_{3}\right)_{2}$ were effective in delaying plant wilting (Table 1). However, leaf necrosis was observed in violas treated with $\mathrm{NaCl}, \mathrm{NaNO}_{3}, \mathrm{BaCl}_{2}$, $\mathrm{Ba}\left(\mathrm{NO}_{3}\right)_{2}$, and mannitol (Table 1, Fig. 2). Treatment of $\mathrm{CaCl}_{2}$ induced stomatal closure and limited transpirational water loss, consequently delaying wilting symptoms (Figs. $3-$ 5, Table 2).

Generally, osmotic treatments extended the shelf life of violas compared with the control treatment (Table 1), indicating that chemical-induced osmotic stress might have caused violas to trigger a response mechanism to temporarily tolerate water deficit stress. Despite the positive effect, $\mathrm{Na}$ and Ba-containing chemicals and mannitol caused severe leaf necrosis, and their aesthetic quality was diminished (Table 1, Fig. 2). A low level of $\mathrm{Na}^{+}$is beneficial in many crops, but the excessive uptake of $\mathrm{Na}^{+}$ can negatively affect cellular biochemistry, leading to plant death (Maathuis, 2013). All barium treatments resulted in leaf necrosis, indicating that $\mathrm{Ba}$-containing chemicals between 200 and $300 \mathrm{~mm}$ were not appropriate agents for violas, although they increased shelf life at the lower concentration. Suwa et al. (2008) reported that barium treatments at 100,1000 , and $5000 \mu \mathrm{M}$ induced phytotoxicity, inhibited photosynthetic activity, and reduced crop production in soybean (Glycine max) in a hydroponic system. Negative effects of mannitol application have been often reported in many studies (Adrees et al., 2015; Fazal et al., 2014; Sassi et al., 2010; Slama et al., 2007). Fazal et al. (2014) reported that mannitol application (137 mM) reduced shoot and root length and biomass of canola (Brassica napus), cauliflower (Brassica oleracea), and tomato (Solanum lycopersicum) seedlings. Mannitol, used as an osmotic-inducing agent in this study, appeared to fail to enhance tolerance to water deficit stress due to tissue damages. It is possible that a lower concentration of $\mathrm{Na}$ and Ba-containing chemicals, and mannitol may not cause side effects. However, the concentrations whose $\psi_{\mathrm{S}}$ was higher than $-1.3 \mathrm{MPa}$ 


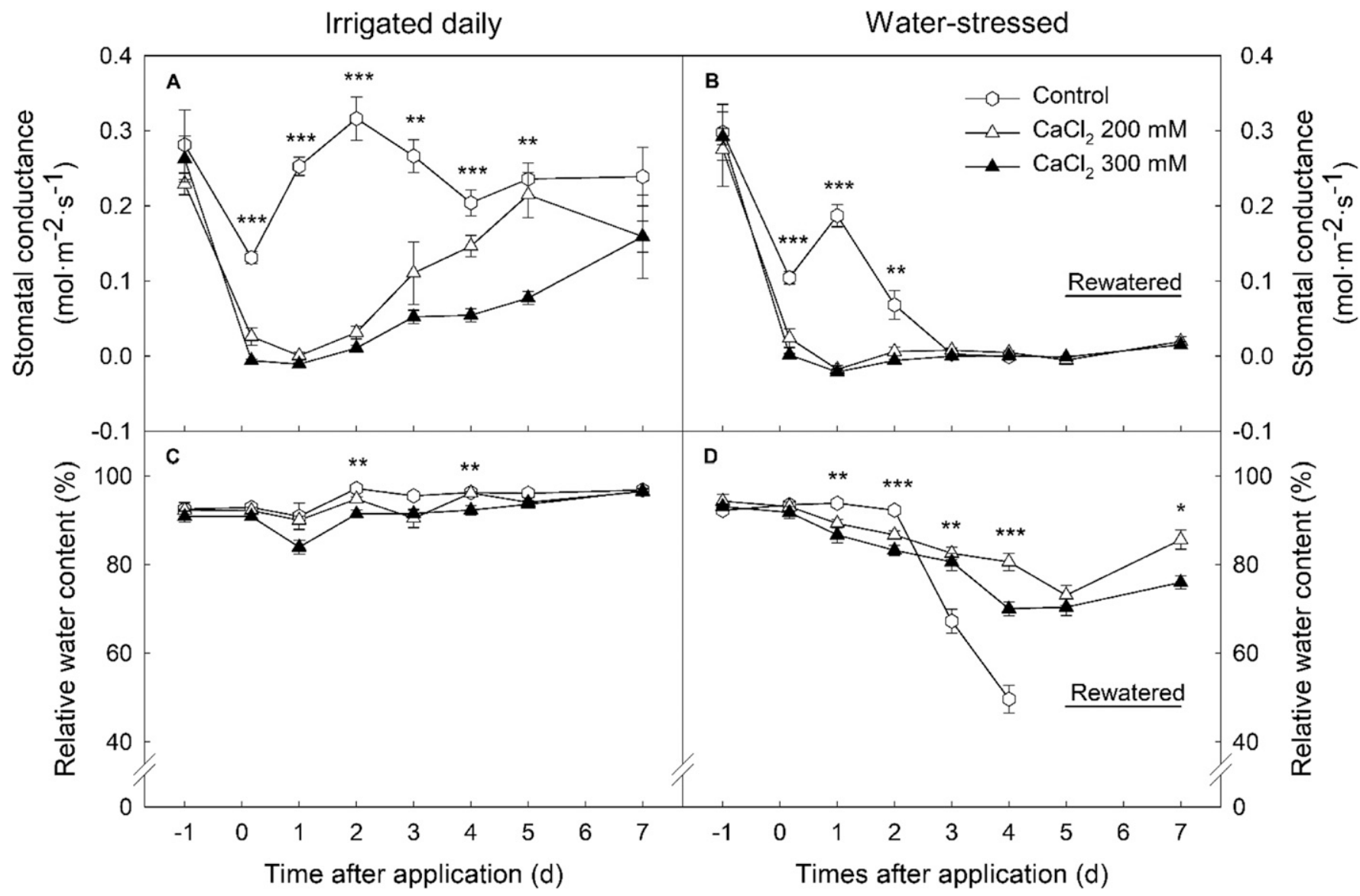

Fig. 5. Stomatal conductance (A and $\mathbf{B})$ and leaf relative water content $(\mathbf{C}$ and $\mathbf{D})$ of $\mathrm{CaCl}_{2}$-treated violas (Viola cornuta). Half of the violas were irrigated daily (A and $\mathbf{C}$ ), and the other half had water withheld until violas had visual wilting symptoms, and irrigation was resumed for $3 \mathrm{~d}$ (B and $\mathbf{D})$. Measurements were performed $1 \mathrm{~d}$ before the application, $4 \mathrm{~h}$ after the application, daily until all violas showed wilting symptoms, and $3 \mathrm{~d}$ after violas were rewatered. Stressed control was not measurable $5 \mathrm{~d}$ after water deficit because they were severely desiccated (B and D). Stressed violas were rewatered on day 5 . Vertical bars are standard errors of the means with five replications $(\mathrm{n}=5)$. *, **,***Significant at $P \leq 0.05,0.01$, or 0.001 , respectively.

did not extend shelf life in the preliminary experiments (S. Park, unpublished data).

Compared with $\mathrm{CaCl}_{2}, \mathrm{Ca}\left(\mathrm{NO}_{3}\right)_{2}$ did not extend shelf life at both concentrations (Table 1). Chloride $\left(\mathrm{Cl}^{-}\right)$is an essential plant nutrient, but the accumulation of $\mathrm{Cl}^{-}$is a significant contributor in salt stress ( $\mathrm{Li}$ et al., 2017a). Geilfus et al. (2015) reported that exposure to $\mathrm{Cl}^{-}$induced stomata closure by modulating the ABA redistribution in Vicia faba, suggesting a salinity stressor, chloride, causes ABA-dependent stomatal closure to save water under salinity stress. Therefore, chloride from $\mathrm{CaCl}_{2}$ treatment, in addition to $\mathrm{Ca}$, might have attributed to inducing stomatal closure and stress mechanisms in this study. Nitrate $\left(\mathrm{NO}_{3}{ }^{-}\right)$might have mitigated the $\mathrm{Ca}$ effect on the stomatal closure, but the exact mode of action of $\mathrm{NO}_{3}{ }^{-}$is unknown.

The treatment of $\mathrm{CaCl}_{2}$ resulted in a sharp reduction of $g_{\mathrm{S}}$ within $4 \mathrm{~h}$ after treatment and a slight reduction of leaf RWC compared with control violas during the water deficit period (Fig. 5). Stomatal closure helps violas to prevent water loss. For example, an application of antitranspirants, chemicals designed to physically block stomata, improved tolerance to water deficit stress (Park et al., 2016). Furthermore, as observed in $\mathrm{CaCl}_{2}$-treated violas irrigated daily, $g_{\mathrm{S}}$ declined rapidly and then gradually increased to the same level of the irrigated controls, suggesting the high concentration of $\mathrm{CaCl}_{2}$ caused stomatal closure immediately after the application (Fig. 5). Therefore, an application of a high concentration of $\mathrm{CaCl}_{2}$ could have induced osmotic stress, and $\mathrm{CaCl}_{2}$-induced osmotic stress could have triggered a mechanism to rapidly close stomata. The subsequent reduction of transpirational water loss might have delayed plant wilting, resulting in enhanced shelf life. Additionally, calcium appeared to alleviate the adverse effects of water deficit stress in this study. Calcium acts as a secondary messenger regulating stress mechanisms that help plants adjust to adverse environments (Ranty et al., 2016). Exogenous calcium treatments have been observed to enhance tolerance in several crops under different abiotic stresses by regulating plant cell metabolism (Shoresh et al., 2011; Tan et al., 2011; Upadhyaya et al., 2011; Xu et al., 2013). The spray treatment of $\mathrm{CaCl}_{2}$ enhanced water deficit tolerance by modulating antioxidant enzyme activities, maintaining the integrity of cell membranes, and increasing photosynthetic efficiency (higher maximum quantum yield of PSII) in Zoysia japonica (Xu et al., 2013). $\mathrm{CaCl}_{2}$ treatment also alleviated water deficit-induced damages and increased photosynthetic performance, such as a high chlorophyll content, in Vernicia fordii ( $\mathrm{Li}$ et al., 2017b). Increases in osmoprotectants (proline, glycine betaine, and total free amino acids) were observed with calcium treatments in Triticum aestivum (Nayyar, 2003), Zea mays (Naeem et al., 2017; Nayyar, 2003), and Catharanthus roseus (Jaleel et al., 2007), suggesting exogenous $\mathrm{Ca}^{2+}$ induces osmotic adjustment under water deficit. In addition to the potential osmotic effect of high concentration of $\mathrm{CaCl}_{2}$, calcium might have contributed to enhancing tolerance as a signal to trigger a responsive mechanism to water deficit stress at the cellular level.

Stomatal conductance of $\mathrm{CaCl}_{2}$-treated violas remained low for at least $2 \mathrm{~d}$ after rewatering (Fig. 5B). After $3 \mathrm{~d}$ of rewatering, $g_{\mathrm{S}}$ and leaf RWC of $\mathrm{CaCl}_{2}$-treated violas remained low compared with the well-watered control (Fig. 5B and D). Oraee and Tehranifar (2020) reported that Viola $\times$ wittrockiana had a slow recovery after 3 weeks of water deficit followed by one week of rewatering. Prolonged stomatal closure and low leaf RWC after rewatering might be due to the characteristic of the viola to recover slowly under water deficit and/or osmotic stress. Under well-watered condition, $g_{\mathrm{S}}$ of $\mathrm{CaCl}_{2}$-treated 
violas was significantly lower than that of the control until $4 \mathrm{~d}$ after treatment (Fig. 5A). This result indicated that osmotic treatment with a higher concentration of $\mathrm{CaCl}_{2}$ maintained stomata closure longer but can be accompanied by compromised plant growth and quality. Prolonged stomatal closure can increase heat stress under high temperatures, reduce photosynthesis, and may cause phototoxicity and necrosis (Kim and van Iersel, 2011; Waterland et al., 2010a, 2010c). However, no side effect was observed in this study.

Even though the treatment of $\mathrm{CaCl}_{2}$ at 200 and $300 \mathrm{~mm}$ was effective in delaying plant wilting and enhancing water deficit tolerance, an excessively higher concentration could reduce the efficacy of $\mathrm{CaCl}_{2}$ treatment on water deficit tolerance. In Expt. 2, $\mathrm{CaCl}_{2}$ $300 \mathrm{~mm}$ started wilting earlier than $\mathrm{CaCl}_{2}$ $200 \mathrm{~mm}$ (Table 2), and a reduction in leaf RWC was observed for $2 \mathrm{~d}$ after $\mathrm{CaCl}_{2}$ treatments compared with the control (Fig. 5D). A high concentration of chemicals can decrease soil water potential lower than plant water potential, pulling water from plant root to soil. The loss of water from the root might exceed the conservation of water by stomatal closure, hastening plant wilting. While the treatment with $300 \mathrm{~mm} \mathrm{CaCl}_{2}$ showed the longest shelf life in Expt. 1, $\mathrm{CaCl}_{2} 300 \mathrm{~mm}$ had a shorter shelf life than $\mathrm{CaCl}_{2} 200 \mathrm{~mm}$ in Expt. 2 (Tables 1 and 2). The efficacy of high concentration might also be dependent on plant stage, size, and/or environmental conditions. Indeed, the light intensity was slightly higher in Expt. 2.

The effects of osmotic treatment were found to increase temporary water deficit stress tolerance in viola. Among the seven chemicals used in this study, $\mathrm{CaCl}_{2}$ treatment was the most effective in enhancing shelf life without any observable side effect. Doubled shelf life by $\mathrm{CaCl}_{2}$ treatment could maintain the crop's aesthetic quality and help crops survive under water deficit until plants are fully irrigated in the postproduction environment. Osmotic treatments could be used to help reduce bedding crop loss due to water deficit stress during the postproduction period. However, caution should be applied to prevent any side effects due to the toxic effect at high concentration and potential damage caused by prolonged stomatal closure. Also, the efficacy of osmotic treatment could be species-dependent. Further research is needed to evaluate the feasibility of using economically viable chemicals and fertilizer applications at high concentrations as an osmotic-inducing agent before shipping, as well as to assess any side effect caused by such applications.

\section{Literature Cited}

Adrees, M., S. Ali, M. Iqbal, S.A. Bharwana, Z. Siddiqi, M. Farid, Q. Ali, R. Saeed, and M. Rizwan. 2015. Mannitol alleviates chromium toxicity in wheat plants in relation to growth, yield, stimulation of anti-oxidative enzymes, oxidative stress and $\mathrm{Cr}$ uptake in sand and soil media. Ecotoxicol. Environ. Saf. 122:1-8.
Armitage, A.M. 1993. Bedding plants: Prolonging shelf performance-Postproduction care and handling. Ball Publishing Co., Batavis, IL.

Arndt, S.K., A. Irawan, and G.J. Sanders. 2015. Apoplastic water fraction and rehydration techniques introduce significant errors in measurements of relative water content and osmotic potential in plant leaves. Physiol. Plant. 155: 355-368.

Bartels, D. and R. Sunkar. 2005. Drought and salt tolerance in plants. Crit. Rev. Plant Sci. 24:23-58.

Beardsell, M.F. and D. Cohen. 1975. Relationships between leaf water status, abscisic acid levels, and stomatal resistance in maize and sorghum. Plant Physiol. 56:207-212.

Fazal, H., A. Muhammad, A. Sartaj, S. Muhammad, U. Rizwan, and A.U. Jan. 2014. Comparative effect of polyethylene glycol and mannitol induced drought on growth (in vitro) of canola (Brassica napus), cauliflower (Brassica oleracea) and tomato (Lycopersicon esculentum) seedlings. Intl. J. Biosci. 4:34-41.

Geilfus, C.M., A. Mithöfer, J. Ludwig-Müller, C. Zörb, and K.H. Muehling. 2015. Chlorideinducible transient apoplastic alkalinizations induce stomata closure by controlling abscisic acid distribution between leaf apoplast and guard cells in salt-stressed Vicia faba. New Phytol. 208:803-816.

Healy, W. 2009. Piles of money. GrowerTalks Mag. 72(12):42-46.

Hossain, M.A., Z.-G. Li, T.S. Hoque, D.J. Burritt, M. Fujita, and S. Munné-Bosch. 2017. Heat or cold priming-induced cross-tolerance to abiotic stresses in plants: Key regulators and possible mechanisms. Protoplasma 255:1-14.

Jaleel, C.A., P. Manivannan, B. Sankar, A. Kishorekumar, R. Gopi, R. Somasundaram, and R. Panneerselvam. 2007. Water deficit stress mitigation by calcium chloride in Catharanthus roseus: Effects on oxidative stress, proline metabolism and indole alkaloid accumulation. Colloids Surf. B Biointerfaces 60:110-116.

Kim, J. and M.W. van Iersel. 2011. Abscisic acid drenches can reduce water use and extend shelf life of Salvia splendens. Scientia Hort. 127:420-423.

Li, B., M. Tester, and M. Gilliham. 2017a. Chloride on the move. Trends Plant Sci. 22:236-248.

Li, X. and F. Liu. 2016. Drought stress memory and drought stress tolerance in plants: Biochemical and molecular basis, p. 17-44. In: M. Hossain, S. Wani, S. Bhattacharjee, D. Burritt, and L.S. Tran (eds.). Drought stress tolerance in plants, Vol. 1. Springer Intl. Publishing, Cham, Switzerland.

Li, Z., X.F. Tan, K. Lu, Z.M. Liu, and L.L. Wu. 2017b. The effect of $\mathrm{CaCl}_{2}$ on calcium content, photosynthesis, and chlorophyll fluorescence of tung tree seedlings under drought conditions. J. Photosyn. 55:553-560.

Maathuis, F.J.M. 2013. Sodium in plants: Perception, signalling, and regulation of sodium fluxes. J. Expt. Bot. 65:849-858.

Naeem, M., M.S. Naeem, R. Ahmad, and R. Ahmad. 2017. Foliar-applied calcium induces drought stress tolerance in maize by manipulating osmolyte accumulation and antioxidative responses. Pak. J. Bot. 49:427-434.

Nayyar, H. 2003. Accumulation of osmolytes and osmotic adjustment in water-stressed wheat (Triticum aestivum) and maize (Zea mays) as affected by calcium and its antagonists. Environ. Exp. Bot. 50:253-264.

Oraee, A. and A. Tehranifar. 2020. Evaluating the potential drought tolerance of pansy through its physiological and biochemical responses to drought and recovery periods. Scientia Hort. $265: 109225$
Park, S., S.A. Mills, Y. Moon, and N.L. Waterland. 2016. Evaluation of antitranspirants for enhancing temporary water stress tolerance in bedding plants. HortTechnology 26:444-452.

Ranty, B., D. Aldon, V. Cotelle, J. Galaud, P. Thuleau, and C. Mazars. 2016. Calcium sensors as key hubs in plant responses to biotic and abiotic stresses. Front. Plant. Sci. 7:327.

Roelfsema, M.R.G., R. Hedrich, and D. Geiger. 2012. Anion channels: Master switches of stress responses. Trends Plant Sci. 17:221-229.

Sassi, S., S. Aydi, K. Hessini, E.M. Gonzalez, C. Arrese-Igor, and C. Abdelly. 2010. Long-term mannitol-induced osmotic stress leads to stomatal closure, carbohydrate accumulation and changes in leaf elasticity in Phaselous vulgaris leaves. Afr. J. Biotechnol. 9:6061-6069.

Savvides, A., S. Ali, M. Tester, and V. Fotopoulos. 2016. Chemical priming of plants against multiple abiotic stresses: Mission possible? Trends Plant Sci. 21:329-340.

Sharma, N., D.R. Waterer, and S.R. Abrams. 2006. Evaluation of abscisic acid analogs as holding agents for bedding plant seedlings. HortTechnology 16:71-77.

Shoresh, M., M. Spivak, and N. Bernstein. 2011. Involvement of calcium-mediated effects on ROS metabolism in the regulation of growth improvement under salinity. Free Radic. Biol. Med. 51:1221-1234.

Slama, I., T. Ghnaya, K. Hessini, D. Messedi, A. Savouré, and C. Abdelly. 2007. Comparative study of the effects of mannitol and PEG osmotic stress on growth and solute accumulation in Sesuvium portulacastrum. Environ. Exp. Bot. 61:10-17.

Suwa, R., K. Jayachandran, N.T. Nguyen, A. Boulenouar, K. Fujita, and H. Saneoka. 2008. Barium toxicity effects in soybean plants. Arch. Environ. Contam. Toxicol. 55:397-403.

Tan, W., Q.-W. Meng, M. Brestic, K. Olsovska, and X. Yang. 2011. Photosynthesis is improved by exogenous calcium in heat-stressed tobacco plants. J. Plant Physiol. 168:2063-2071.

Tuteja, N. and S. Mahajan. 2007. Calcium signaling network in plants: An overview. Plant Signal. Behav. 2:79-85.

Upadhyaya, H., S.K. Panda, and B.K. Dutta. 2011. $\mathrm{CaCl}_{2}$ improves post-drought recovery potential in Camellia sinensis (L) O. Kuntze. Plant Cell Rpt. 30:495-503.

Wang, F., H. Yamamoto, and Y. Ibaraki. 2008. Measuring leaf necrosis and chlorosis of bamboo induced by typhoon 0613 with RGB image analysis. J. For. Res. 19:225-230.

Wang, W., B. Vinocur, and A. Altman. 2003. Plant responses to drought, salinity and extreme temperatures: Towards genetic engineering for stress tolerance. Planta 218:1-14.

Waterland, N.L., C.A. Campbell, J.J. Finer, and M.L. Jones. 2010a. Abscisic acid application enhances drought stress tolerance in bedding plants. HortScience 45:409-413.

Waterland, N.L., J.J. Finer, and M.L. Jones. 2010b. Abscisic acid applications decrease stomatal conductance and delay wilting in drought-stressed chrysanthemums. HortTechnology 20:896-901.

Waterland, N.L., J.J. Finer, and M.L. Jones. 2010c Benzyladenine and gibberellic acid application prevents abscisic acid-induced leaf chlorosis in pansy and viola. HortScience 45:925-933.

Xu, C., X. Li, and L. Zhang. 2013. The effect of calcium chloride on growth, photosynthesis, and antioxidant responses of Zoysia japonica under drought conditions. PLoS One 8:e68214.

Zhang, J., W. Jia, J. Yang, and A.M. Ismail. 2006. Role of ABA in integrating plant responses to drought and salt stresses. Field Crops Res. 97:111-119. 